\title{
Influence of Temperature and Pressure Change on Adiabatic and Isothermal Methanation Processes
}

\author{
Jekaterina Porubova ${ }^{1}$, Marco Klemm ${ }^{2}$, Isabel Kiendl ${ }^{3}$, Karlis Valters ${ }^{4}$, Darja Markova ${ }^{5}$, Mara Repele ${ }^{6}$, Gatis \\ Bazbauers ${ }^{7},{ }^{1,4-7}$ Riga Technical University, Institute of Energy Systems and Environment; \\ ${ }^{2,3}$ Deutsches Biomasse Forschungs Zentrum
}

\begin{abstract}
Energy plans of many countries anticipate an increased use of biomethane for energy supply, i.e., in power and heat production as well as in the transport sector. Existing infrastructure of natural gas storage, supply and application provides a good platform to facilitate transfer to biomethane utilization on a larger scale. One key element of the biomethane system is the upgrade of the biomass-derived synthesis gas originating from different sources, to a quality of natural gas (SNG - Synthesis Natural Gas) via the methanation process for further injection into the natural gas grid.. The maximisation of efficiency of the methanation process is of critical importance in order to make biomethane technology viable for wider application. The aim of the study was to improve efficiency of the methanation process by finding the optimum temperatures and pressure. Theoretical modelling of adiabatic and isothermal methanation processes by using thermodynamic equilibrium calculations was introduced as a method for the study. The results show the impact of temperature and pressure changes on the overall efficiency of methane production. It can be concluded from the study that knowledge about the relation between temperature, pressure and the efficiency of the methanation process makes it possible to optimize the process under various biomass synthesized gas input conditions.
\end{abstract}

Keywords - biomethane, syngas, adiabatic, isothermal, methanation, SNG, thermodynamic equilibrium modeling, renewable energy sources

\section{INTRODUCTION}

In many countries around the world, the use of fossil fuels is entrenched in the national energy sector. Through extensive use of fossil fuels, the following problems evolve - climate change, environmental pollution and energy dependence on import of many countries that also stimulates increase of prices of electricity, heat and energy resources. Development of sustainable energy systems can reduce a share of fossil energy sources in the energy sector. Development of sustainable energy systems is based on replacement of fossil fuels with renewable energy sources to the maximum extent.

In the Latvian energy sector, the main renewable energy sources are provided by water at large hydro power stations and by biomass used in the individual heating installations of the household sector as well as the boiler plants of the district heating sector. Increase of the use of biomass in the Latvian energy sector can help to decrease the total dependence on fossil fuels, especially on natural gas.

The main target of Directive 2003/30/EC was to stimulate the use of renewable energy, including use of biofuel in the transport sector. The Directive defines that the total consumption of biofuel in the transport sector in the EU member states had to reach $2 \%$ in 2005 and $5,75 \%$ in 2010 [1]. Unfortunately, Latvia did not achieve this goal and the total share of biofuel was only $2,6 \%$ in 2010 [2]. The collective target set among the member states of the European Union for renewable energy usage is defined in Directive 2009/28/EC [3]. The Latvian goal is to reach a level of $37 \%$ of the primary renewable energy use in the national energy balance by the year 2016 [4]. The guidelines [4], however, had established that in 2010 the amount of the produced electricity from renewable sources (RES) had to reach $49,3 \%$ of the total consumed electricity, but in reality only $48,5 \%$ of the RES were produced [5]. According to the draft of the Latvian energy sector development strategy until 2030 (Latvian energy strategy) developed by the Ministry of Economy, one of the main goals is to reduce import of natural gas from the existing supplier by $50 \%$ [6]. The use of biomethane can help to achieve this goal of the Latvian energy strategy.

The methane production from biomass can occur in two ways and, depending on the chosen extraction method, the operation conditions and the final products can vary [7]:

a) thermo-chemical conversion of biomass, leading to biomethane;

b) bio-chemical conversion of biomass, leading to bio-gas.

The main differences between these two methods are tha,t during the thermo-chemical conversion, biomass gasification is followed by the methanation process, but bio-gas production occurs during the anaerobic digestion of biomass. In addition, thermo-chemical conversion of biomass is characterized by a higher time efficiency compared to bio-chemical conversion. The efficiency is higher, because the thermochemical conversion requires a lower reaction time with a few seconds or minutes and several days, weeks or even more for the anaerobic digestion of biomass [8].

Below are the main reactions of the thermo-chemical methanation process: $[5,9]$ :

$$
\begin{array}{lr}
\mathrm{CO}+3 \mathrm{H}_{2} \leftrightarrow \mathrm{CH}_{4}+\mathrm{H}_{2} \mathrm{O} & \Delta \mathrm{H}_{\mathrm{R}}=-206,28 \mathrm{~kJ} / \mathrm{mol} \text { (1.1) } \\
\mathrm{CO}_{2}+4 \mathrm{H}_{2} \leftrightarrow \mathrm{CH}_{4}+2 \mathrm{H}_{2} \mathrm{O} & \Delta \mathrm{H}_{R}=-165,12 \mathrm{~kJ} / \mathrm{mol}(1.2) \\
\mathrm{CO}+\mathrm{H}_{2} \mathrm{O} \leftrightarrow \mathrm{H}_{2}+\mathrm{CO}_{2} & \Delta \mathrm{H}_{R}=-41,16 \mathrm{~kJ} / \mathrm{mol}(1.3) \\
\mathrm{C}_{2} \mathrm{H}_{4}+2 \mathrm{H}_{2} \mathrm{O} \leftrightarrow 2 \mathrm{CO}+4 \mathrm{H}_{2} & \Delta H_{R}=+210 \mathrm{~kJ} / \mathrm{mol}(1.4)
\end{array}
$$


Reactions (1.1) - (1.3) are exothermic, while the reaction (1.4) requires additional heat input (endothermic character).

Methanation technologies are being developed and researched since approximately the 1950s. Fixed bed or adiabatic methanation technology was developed to achieve needed heat condition and to extend the use of catalysis [10]. By the use of fluidized bed methanation reactor it is possible to achieve practical isothermal conditions and, at the same time by isothermal methanation the synthetic gas and fluidized bed reactor working material are better mixed than by fixed bed methanation reactor [11].

Table I summarizes the main differences between the two existing methanation processes - adiabatic and isothermal.

TABLE I

THE MAIN DIFFERENCES BETWEEN ISOTHERMAL AND ADIABATIC METHANATION PROCESSES $[12,13,14]$

\begin{tabular}{|l|l|l|}
\hline & $\begin{array}{l}\text { Adiabatic } \\
\text { methanation }\end{array}$ & $\begin{array}{l}\text { Isothermal } \\
\text { methanation }\end{array}$ \\
\hline Type of the reactor & Fixed bed & Fluidized bed \\
\hline $\begin{array}{l}\text { Working } \\
\text { temperature, } \mathrm{K}\end{array}$ & $513-873$ & $\sim 573$ \\
\hline Pressure, bar & $20-100$ & $1-20$ \\
\hline Advantages & Simple construction & $\begin{array}{l}\text { Good heat and mass } \\
\text { exchange processes }\end{array}$ \\
\hline Disadvantages & Complex heat transfer & $\begin{array}{l}\text { Working material } \\
\text { maintenance }\end{array}$ \\
\hline
\end{tabular}

The benefits of adiabatic methanation (Table I) are (relatively) simple equipment construction and maintenance.

The purpose of the modelling of the methanation process is to determine how the process and its efficiency (the yield of methane) are affected by changes of the process parameters, specifically, by changes of the methanation pressure and temperature.

\section{METHODS}

The adiabatic (Figure 1) and isothermal (Figure 2) methanation processes are studied by using thermodynamic equilibrium models and with help of Aspen Plus ${ }^{\circledR}$ software. This program is intended for modelling chemical processes and their detailed analysis, as well as the determination of the mass and energy balance [15].

The ranges of values of the pressure and temperature used in the modelling of both processes are shown in Table II. Temperature and pressure are the most important factors influencing the equilibrium composition in the methanation process [16].

The principal process schemes of methanation which were created with the simulation program can be seen in Figures 1 2. Gibb's reactors were used as methanation reactors in all models. It is assumed that there is no pressure loss in the system. The final step in all models after the methanation process is water removal from the synthesis product which is ensured by a flow separator, where the water condensation takes place.

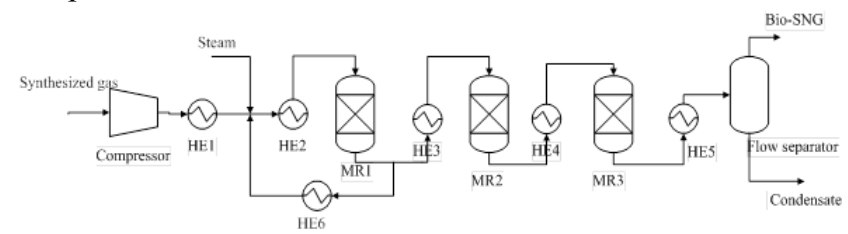

Fig. 1. Process scheme of adiabatic methanation (HE - heat exchanger, MR methanation reactor) [17].

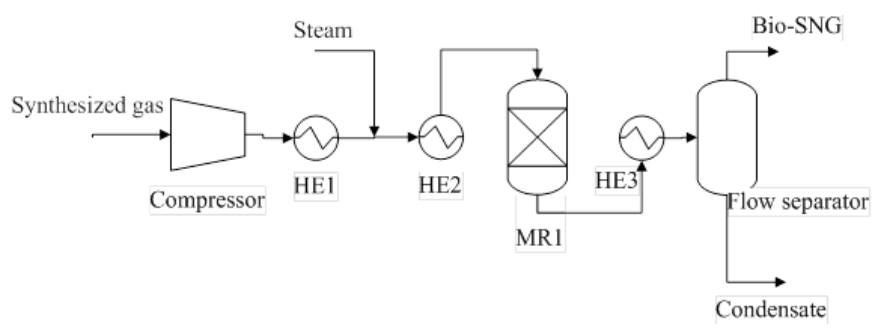

Fig. 2. Process scheme of isothermal methanation [16]

TABLE II

THE RANGE OF VARIABLE VALUES OF PRESSURE AND TEMPERATURE, WHICH ARE USED IN THE MODELLING OF BOTH METHANATION PROCESSES

\begin{tabular}{|l|c|c|}
\hline \multicolumn{1}{|c|}{ Parameter } & T, K & P, bar \\
\hline $\begin{array}{l}\text { Adiabatic } \\
\text { metanation }\end{array}$ & $513-873$ & $2-100$ \\
\hline $\begin{array}{l}\text { Isothermal } \\
\text { metanation }\end{array}$ & $373-673$ & $2,5-20$ \\
\hline
\end{tabular}

Table III shows the composition of the synthesis gas upstream of the methanation reactor that was used in all simulation models. This composition of the synthesis gas is typical for Güssing type gasifiers. The composition of the input synthesis gas upstream of the methanation reactor was always defined as constant for all simulations.

TABLE III

COMPOSITION OF THE SYNTHESIS GAS UPSTREAM OF METHANATION REACTOR [14]

\begin{tabular}{|c|c|}
\hline Component & Amount, vol\% \\
\hline $\mathrm{CO}$ & 22 \\
\hline $\mathrm{CO}_{2}$ & 22 \\
\hline $\mathrm{N}_{2}$ & 2 \\
\hline $\mathrm{H}_{2}$ & 39 \\
\hline $\mathrm{CH}_{4}$ & 10 \\
\hline $\mathrm{C}_{2} \mathrm{H}_{4}$ & 3 \\
\hline $\mathrm{C}_{3} \mathrm{H}_{6}$ & 1 \\
\hline $\mathrm{C}_{2} \mathrm{H}_{6}$ & 1 \\
\hline
\end{tabular}


The most important input parameters that were defined for adiabatic and isothermal methanation are summarized in Table IV where the assumptions regarding the total synthesis gas flow, steam flow and synthesis gas input temperature are shown.

\section{TABLE IV}

INPUT OF REFERENCE PARAMETERS FOR METHANATION PROCESS MODELS [17]

\begin{tabular}{|c|c|c|}
\hline Parameter & $\begin{array}{l}\text { Adiabatic } \\
\text { metanation }\end{array}$ & $\begin{array}{l}\text { Isothermal } \\
\text { metanation }\end{array}$ \\
\hline $\begin{array}{c}\text { Methanation } \\
\text { pressure, bar }\end{array}$ & 20 & 2.5 \\
\hline $\begin{array}{c}\text { Compressor } \\
\text { pressure, bar }\end{array}$ & 1 \\
\hline Input temperature, $\boldsymbol{2}$ \\
\hline Synthesized gas & 290 \\
\hline Steam & 573 \\
\hline $\begin{array}{c}\text { Methanation } \\
\text { reactor 1 (MR1) }\end{array}$ & 573 \\
\hline $\begin{array}{c}\text { Methanation } \\
\text { reactor 2 (MR2) }\end{array}$ & 523 \\
\hline $\begin{array}{c}\text { Methanation } \\
\text { reactor 3 (MR3) }\end{array}$ & 523 \\
\hline Flow separator & 298 \\
\hline Total flow, $k m o l / s$ \\
\hline Synthesized gas & \multicolumn{2}{|c|}{10} \\
\hline Steam & \multicolumn{2}{|c|}{1} \\
\hline \multicolumn{2}{|c|}{} \\
\hline
\end{tabular}

Figure 1 shows the adiabatic methanation process. Three adiabatic methanation reactors were used in this case. As it is shown in Figure 1, there is a partial gas recirculation, which is necessary due to temperature regime. The partial gas recirculation dilutes the incoming synthesis gas in the first methanation reactor (MR1) and leads to decreased heat development due to the exothermic reactions. In adiabatic methanation heat exchangers are used upstream of each reactor (see Figure 1), as it is necessary that the temperature of input flows in the reactors should be around 523 - $573 \mathrm{~K}$ [10], because this are typical input methanation temperature by adiabatic process.

When comparing isothermal (Figure 2) and adiabatic methanation (Figure 1), it can be said that isothermal methanation requires only one methanation reactor (adiabatic process - three).

\section{RESULTS AND DISCUSSION}

\section{A. Adiabatic methanation}

The Figure 3 shows $\mathrm{CH}_{4}, \mathrm{CO}, \mathrm{CO}_{2}$ and $\mathrm{H}_{2}$ output flow values downstream of methanation reactors depending on changes of methanation temperature in adiabatic process with constant pressure.

As it is defined in [17], the high nitrogen concentration in synthesized gas can reduce methanation temperature leading to increase of the total methane flow. At the same time, output methane flow $\left(\mathrm{CH}_{4}\right)$ depends also on input carbon dioxide $\left(\mathrm{CO}_{2}\right)$ and hydrogen $\left(\mathrm{H}_{2}\right)$ flows, as it is shown in reactions $(1.1)-(1.4)$.
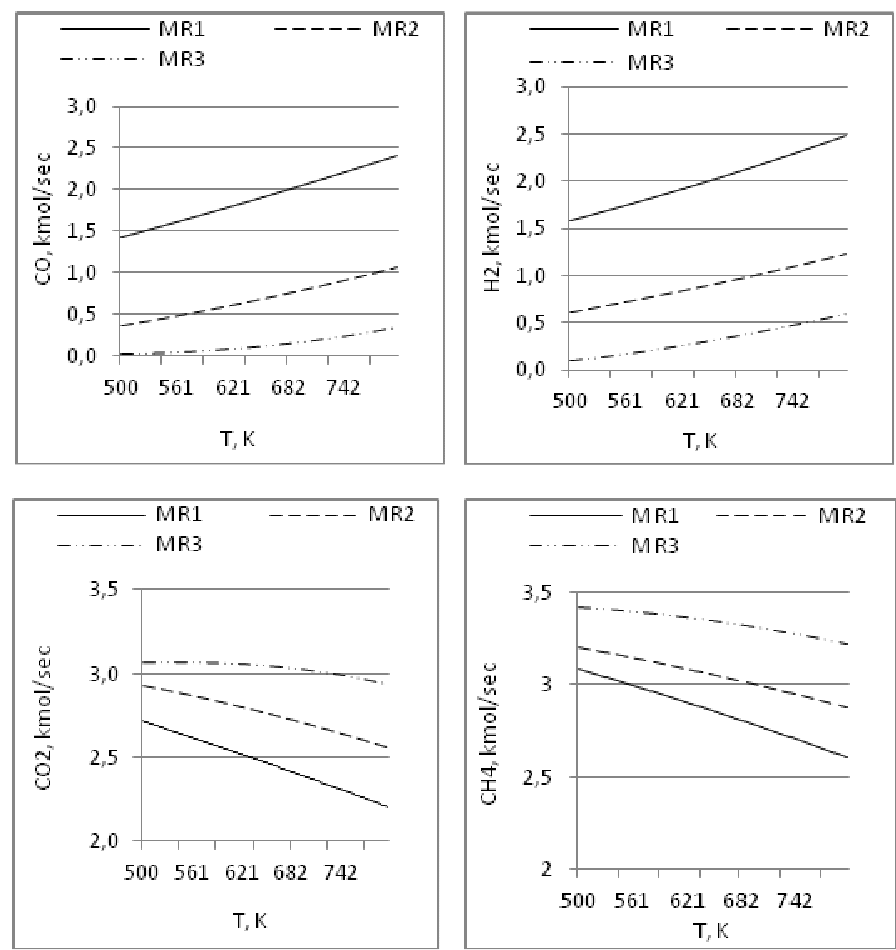

Fig. 3. $\mathrm{CH}_{4}, \mathrm{CO}, \mathrm{CO}_{2}$ and $\mathrm{H}_{2}$ output flow depending on changes of methanation input temperature in adiabatic process (synthesis gas composition - constant, pressure -20 bar).

With increase of methanation temperature from 500 to 800 $\mathrm{K}$ output flow of carbon dioxide decreases, but at the same time the output flow of hydrogen increases (Figure 3).

The largest difference between initial and final values of components in the output flow, as shown in Figure 3, is in the first methanation reactor (MR1). The outcoming methane flow downstream of the first methanation reactor decreases from 3,1 to $2,6 \mathrm{kmol} / \mathrm{sec}$, by a temperature change from 500 to 800 $\mathrm{K}$. The same output flow growing tendency is obtained for carbon dioxide - the $\mathrm{CO}_{2}$ output flow is decreasing, but hydrogen and carbon monoxide have increasing flows. At the same time, methane outcome downstream of the second methanation reactor (Figure 3- "MR2") decreases approximately by $0,3 \mathrm{kmol} / \mathrm{sec}$. As it is shown in Figure 3, hydrogen output flow downstream of the second reactor (Figure 3 - "MR2") increases from 0,5 to $1,2 \mathrm{kmol} / \mathrm{sec}$, but hydrogen output flow from the third methanation reactor grows to $0,5 \mathrm{kmol} / \mathrm{sec}$. This indicates that the hydrogen outcome flow increase is more significant than the decrease of the methane flow (see 1.1. reaction). The difference of carbon monoxide flow downstream of the third methanation reactor in the temperature range from 500 to $700 \mathrm{~K}$ is $0,322 \mathrm{kmol} / \mathrm{sec}$. It means that the decrease of carbon monoxide output flow change within the temperature range from 500 to $700 \mathrm{~K}$ is equal to 15 [vol. $-\%$ ]. 


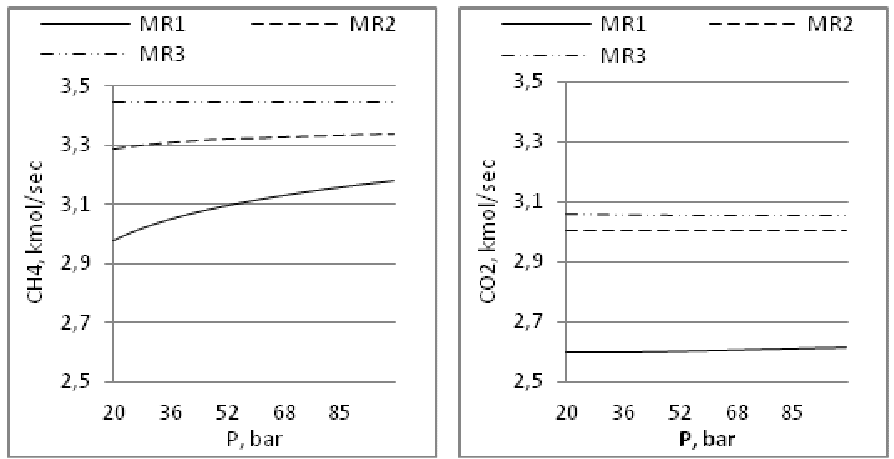

Fig. 4. $\mathrm{CH}_{4}$ and $\mathrm{CO}_{2}$ output flow depending on changes of methanation pressure in adiabatic process $\left(\mathrm{T}_{\mathrm{MR} 1}=573 \mathrm{~K}, \mathrm{~T}_{\mathrm{MR} 2-3}=523 \mathrm{~K}\right.$, synthesis gas composition - constant, $\mathrm{MR}$ - methanation reactor).

The influence of pressure change can be seen in Figure 4. As it is shown in Figure 4, pressure change practically does not influence carbon dioxide flow, i.e. carbon dioxide flow downstream of first methanation reactor increases by $0,0137 \mathrm{kmol} / \mathrm{sec}$, downstream of second only by $0,0098 \mathrm{kmol} / \mathrm{sec}$, and downstream of third the carbon dioxide flow difference achieves $0,0063 \mathrm{kmol} / \mathrm{sec}$. In the same time, the methane output (?) flow increases with the pressure. On the other hand, Figure 4 shows that only methane output from reactor MR1 and MR2 depends on the pressure. Methane output from reactor MR3 is so small that this flow change cannot be seen in Figure 4, but in the absolute value methane output flow change after MR3 is equal to $0,0245 \mathrm{kmol} / \mathrm{sec}$ or 0,72 [vol. - \%].

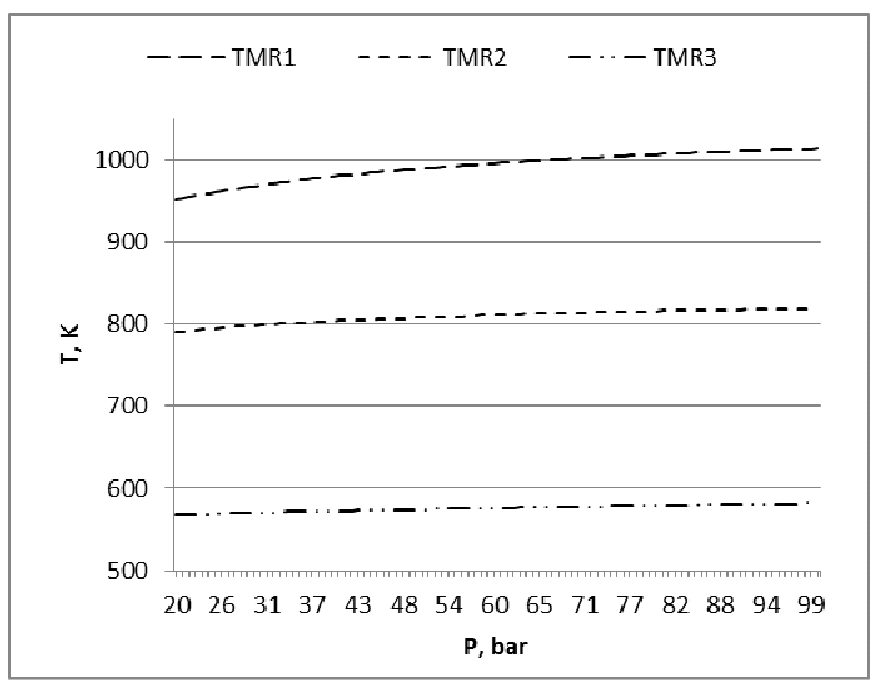

Fig. 5. Influence of pressure changes on output temperature downstream of methanation reactors in adiabatic process (synthesis gas composition constant,).

Figure 5 shows that with increasing methanation pressure, the temperature has a tendency to increase as well, and methane output decreases with temperature increase (Figure 3 ). At the same time, with an increase of methanation pressure at constant input temperature, methane output downstream of methanation reactors increases (Figure 4). As can be seen in Figure 5, pressure influences methanation output temperature in adiabatic process. With pressure increase the methanation output temperature increases as well. The methanation temperature and methane flow are increasing with rising pressure, because the methanation reactions have a tendency to reach equilibrium condition and with an increase of methanation pressure, the equilibrium condition is directed.

\section{B. Isothermal methanation}

In the isothermal methanation process, with increasing temperature the values of carbon monoxide, carbon dioxide and hydrogen flows rise and methane flow decreases (see Figure 6). The main difference comparing the temperature increase influence of isothermal and adiabatic methanation process is that in case of adiabatic process output carbon dioxide flow after all methanation reactors are decreasing, but in isothermal process $\mathrm{CO}_{2}$ output flow is increasing.

By isothermal methanation in temperature range from 373 to $518 \mathrm{~K}$ there is nearly constant methane and carbon monoxide flow. The increase of carbon monoxide flow begins at $560 \mathrm{~K}$ (see Figure 6).
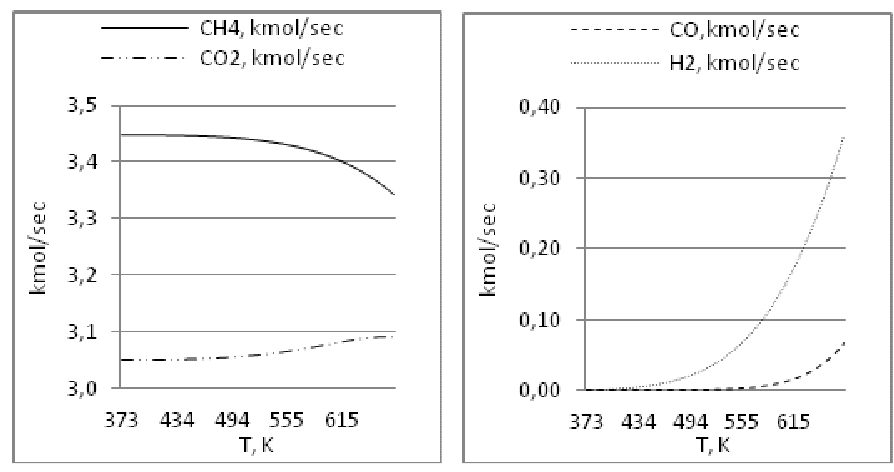

Fig. 6. $\mathrm{CH}_{4}, \mathrm{CO}, \mathrm{CO}_{2}$ and $\mathrm{H}_{2}$ output flow downstream of methanation reactor depending on changes of methanation temperature in isothermal process (pressure - 2,5 bar, synthesis gas composition - constant).

The influence of temperature change on carbon dioxide growth can be seen in Figure 6. Therefore, in isothermal methanation process it is necessary to ensure a low operating temperature to avoid the formation of carbon dioxide. The presence of carbon dioxide in methanation reactions can change direction of reaction against methane formation (see 1.1. - 1.4. reactions).

Methane outcoming flow decreases depending on change of methanation temperature in isothermal methanation (see Figure 6) due to several reasons. The first reason is that by increasing the methanation temperature the equilibrium condition is directed in educts direction. The second reason is that in the system is more hydrogen that can be used in reaction (see reaction (1.1) - (1.4). As illustrated in reaction (1.1) - (1.4) not only from $\mathrm{CO}_{2}$ and hydrogen it possible to produce methane, most important is carbon monoxide methanation - main methanation reactor (Reaction (1.1)).

As can be seen in Figure $6, \mathrm{CO}_{2}$ and hydrogen output flows increase with rising temperature, which means that in methanation reactions the conversation of carbon dioxide does not play a significant role. At the same time the equilibrium composition depends on methanation temperature - with temperature increase the methane output will decrease. 
Influence of pressure on methanation reactions in isothermal model is shown in Figure 7.

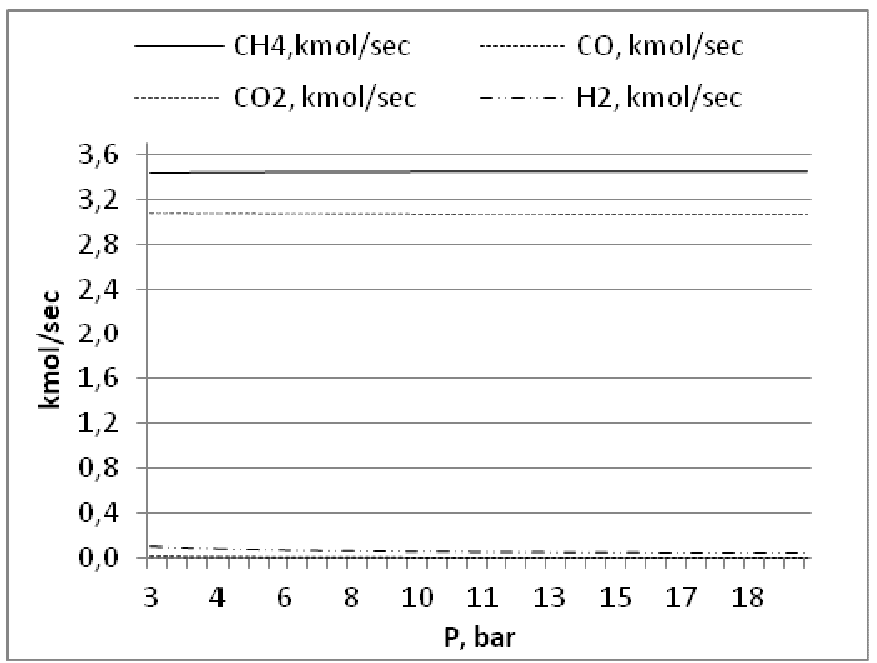

Fig. 7. $\mathrm{CH}_{4}, \mathrm{CO}, \mathrm{CO}_{2}$ and $\mathrm{H}_{2}$ output flow depending on changes of methanation pressure in isothermal process $(\mathrm{T}=573 \mathrm{~K}$, synthesis gas composition - constant)

At constant methanation temperature $(573 \mathrm{~K})$ pressure changes have minimal influence on methane formation, carbon monoxide and carbon dioxide flows and also on hydrogen flow, because by $573 \mathrm{~K}$ temperature the equilibrium condition are achieved and small pressure changes do not have a significant influence on synthesized gas composition flows.

When influence of temperature on methane yield in isothermal and adiabatic methanation processes is compared (Figure 3,6), it can be seen that at lower temperature values in case of both methanation processes the maximal value of methane output can be achieved if other conditions are kept equal.

\section{CONCLUSIONS}

The results of this work indicate that the temperature change has a greater impact on the outcome of methane in adiabatic methanation than the pressure change. Temperature decrease in adiabatic methanation can be achieved not only with nitrogen dilution [17], but also with decreasing of the pressure value. That means that at higher pressure the methanation temperature value are higher cause methanation reactions state the equilibrium to shift. In case of isothermal methanation, only temperature decrease can increase the methane yield. Comparisons of influence of pressure changes on isothermal and adiabatic process allow to conclude that in adiabatic methanation, by constant incoming temperature, methane outcome downstream of the first and second reactors increases with the pressure increase. In case of isothermal methanation, the pressure change does not have a significant influence on the methane yield, but in the same time by so low pressure values, which were used in isothermal methanation process model, the carbon monoxide and hydrogen conversation to methane show good results.

\section{REFERENCES}

1. DIRECTIVE 2003/30/EC OF THE EUROPEAN PARLIAMENT AND OF THE COUNCIL (8 May 2003) on the promotion of the use of biofuels or other renewable fuels for transport.

2. Informative Report about the state of the biofuels industry from Latvian Ministry of Economy -10.04.2012, 22. pp. (in Latvian)

3. DIRECTIVE 2009/28/EC OF THE EUROPEAN PARLIAMENT AND OF THE COUNCIL of 23 April 2009 on the promotion of the use of energy from renewable sources and amending and subsequently repealing Directives 2001/77/EC and 2003/30/EC. L 140/16 EN Official Journal of the European Union 5.6.2009

4. Atjaunojamo energoresursu izmantošanas pamatnostādnes 2006.2013.gadam (informatīvā daļa) Rīga 2006.gads, 55 lpp.

5. Renewable energy sources

http://www.em.gov.lv/em/2nd/?cat=30170 - [02.07.2011]

6. “Enerǵêtikas stratēǵija 2030" - Projekts, LR Ekonomikas ministrija, 68 lpp.

http://www.bra.lv/images/editor/31082011\%20-

$\% 20$ Energetikas $\% 20$ strategija $\% 202030 \% 20$ projekts $\% 20 \% 282 \% 29$.pdf [26.03.2012]

7. Perimenis A., Walimwipi H., Zinoviev S., Müller-Langer F., Miertus S. Development of a decision support tool for the assessment of biofuels, Energy Policy, 2011, vol. 39, p. 1782-1793

8. Zhang L., Xu C. (Charles), Champagne P. Overview of recent advances in thermo-chemical conversion of biomass, Energy Conversion and Management, 2010, vol. 51, p. 969-982

9. Gasifipedia Supporting Technologies http://www.netl.doe.gov/technologies/coalpower/gasification/gasifipedia /5-support/5-12 methanation.html - [29.03.11]

10. Kopyscinskin J., Schildhauer J.T. and Biollaz S.M.A. Production of synthetic natural gas (SNG) from coal and dry biomass - A technology review from 1950 to 2009, Fuel, 2010, vol. 89, p. 1763-1783

11. Ortwein A., Rönsch S., Klemm M., and Kaltschmitt M. Methanation - Basics, Technologies and Integration into Thermo-chemical Biorefineries - International Conference on Polygeneration Strategies 2010, Leipzig, 2010, 9 p.

12. Sudiro M., Zanella C., Bressan L., Fortana M. and Bertucco A., (2009) Synthetic natural gas (SNG) from petcoke: model development and simulation, AIDIC Conference Series, 09, 309-318 DOI:10.3303/ACOS0909036

13. Klemm M., Ortwein A., Zeymer M. et al. 'Gasreinigung und Konditionierung - Stand der Technik und Gesamtkonzepte für Methanisierungsanlage, 1. International Biomass Conference, Leipzig, 4. Mai 2010

14. Rauch R. ,Results on production of BioSNG from product gas of a dual fluidised bed gasifier" - Institute of Chemical Engineering Working Group Future Energy Technology Prof. Hermann Hofbauer, Vienna University of Technology

15. http://www.vtu.com/Prozess-Simulation/de/1515/b/11

16. Ebbing D.D., Gammon S.D. General Chemistry. Ninth Edition, Cengage Learning, 2007, USA, pp. 1030

17. Porubova J., Bažbauers G., Markova D. (2011) Modeling of the Adiabatic and Isothermal Methanation Process, Scientific Journal of $R T U$ 13. Series, Environmental and Climate Technologies - 6 Issue, 79.84. p.

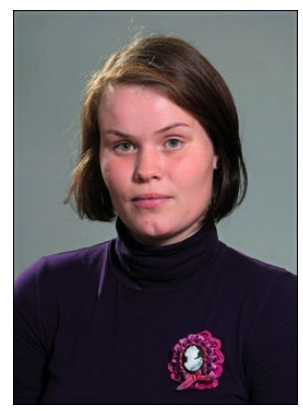

Jekaterina Porubova, $\mathrm{PhD}$ student, researcher of Institute of Energy Systems and Environment of RTU. Jekaterina Porubova has been part of academic staff of Faculty of Energy and Electrotechnics, Riga Technical University since 2010. The main research area is renewable energy resources, biofuel and exergy. Master thesis "Analysis of Long-Term Plan for Energy Supply System for Latvia that is $100 \%$ Based on the Use of Local Energy Resources" was defended in Institute of Energy Systems and Environment, Riga (2010) and for this work received Jekaterina Porubova in year 2011 Werner von Siemens Excellence Award.

Address: Kronvalda boulv. 1, LV-1010, Riga, Latvia

Phone: +371 67089911, Fax: +371 67089908

E-mail: jekaterina.porubova@rartu.lv 


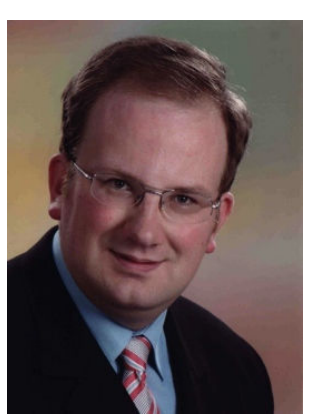

Marco Klemm, Dr.-Ing. studied mechanical engineering at the Technical University of Chemnitz and did his $\mathrm{PhD}$ at the Technical University of Dresden at the Chair of Power Plant Systems. His doctoral-thesis dealt with 'Hot tar removal of burnable gas from biomass gasification using catalytic partial oxidation'. He worked as a scientist and project leader in the fields of energetic biomass utilization and carbon dioxide capture and storage. He was leader of the working-field "Biomass and Waste Energy" at the Chair of Combustion, Heat and Mass Transfer at the Technical University of Dresden. Within the framework of his work he held lectureships at the Technica University of Dresden and Technical University of Clausthal. Currently Marco Klemm is team leader Synthesis Gas Supply in the Department Biorefineries at the German Biomass Research Centre (DBFZ). He is the author of a number of articles in magazines and has made contributions at national and international conferences and workshops. Marco Klemm is coinventor in several patents.

Address: DBFZ Deutsches Biomasseforschungszentrum gemeinnützige GmbH (DBFZ), Torgauer Str. 116, D - 04347 Leipzig, Germany

E-mail: marko.klemm@dbfz.de

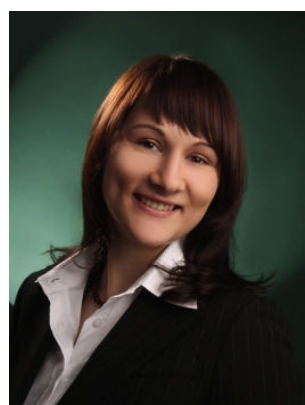

Isabel Kiendl, Dipl.-Ing., studied environmental engineering at the University of Bayreuth. The main field of her study was energy science, especially energy-related biomass use. During this time she was research assistant for biomass pyrolysis at the chair of chemical engineering, University of Bayreuth. The subject of the diploma thesis was the immobilization of novel catalyst supports for the Fischer-Tropsch Synthesis. Since July 2011 she works as scientist in the field of methanation in the team synthesis gas supply in the Department Biorefineries at the Deutsches Biomasse Forschungs Zentrum (DBFZ).

\section{E-mail: isabel.kiendl@dbfz.de}

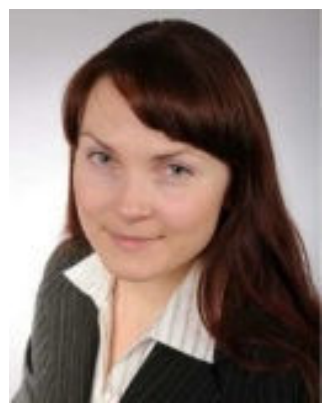

Darja Markova, Dr.sc.ing., senior researcher, Riga Technical University, Energy Systems and Environment. Darja Markova has been part of academic staff of Faculty of Energy and Electrotechnics, Riga Technical University since 2007. The main research topics are district heating, bioenergy systems as well as hydrogen production. She has participated in different local projects related to energy as well as is author of more than 10 publications. She has Bachelor (2003) and Master (2005) of Environmental Science Diploma. PhD thesis "Research of bioethanol reforming and hydrogen production processes for use in fuel cell equipment" was defended in Riga Technical University (2009), where a part of experimental work was carried out during scholarship of German Environmental Foundation in Fraunhofer Institute for Solar Energy Systems (2006).

E-mail: darja.markova@rtu.lv

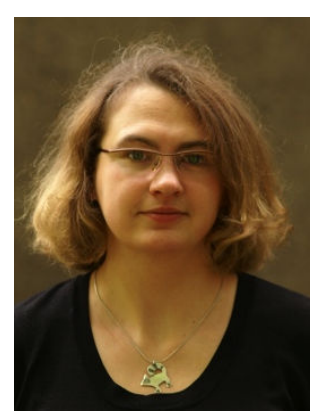

Mara Repele, PhD student of the Institute of Energy Systems and Environment at Riga Technical University, has Master Degree in Geology (2004) and Master Degree in Environmental Science (2009). The main field of study is ecodesign and life cycle assessment of building materials.

Māra Rēpele currently works as a Forensic Scientist at the Biological and Chemical Investigation Department at the State Forensic Science Bureau, 55 Hospitalu Street, Riga, Latvia. Previously she worked as a Geologist at the Institute of Geology and as a Technician at the Laboratory of Rock Research at the University of Latvia.

Māra Rēpele received the Letter of distinction of the Rector of the University of Latvia for researches in geology (2004) and Werner von Siemens Excellence Award for Master's thesis "Development of method for ecodesign" (2009).

E-mail: mara.repele@rtu.lv

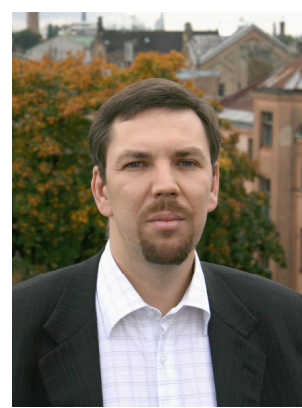

Karlis Valters. Karlis Valters has graduated from the University of Latvia (biorganic and environmental chemistry). His $\mathrm{PhD}$ Karlis earned at the Department of Environmental Chemistry, Stockholm University and his thesis was dedicated to levels and bioaccumulation mechanisms of persistent organic pollutants (POPs) in fish and birds in Latvia. Valters has been a visiting scholar at the University of Wisconsin-Madison on a scholarship from the American Chemical Society. He spent two years as a postdoctoral fellow at the Great Lakes Institute for Environmental Research, University of Windsor, Ontario, Canada. His research there revolved around uptake, exposure and effects of polycyclic aromatic hydrocarbons (PAH) in bottom feeding fish in aquaria and the Detroit river. Since 2006 Valters is a docent at the Institute of Energy Systems and Environment, Riga Technical University. E-mail: karlis.valters@rtu.lv

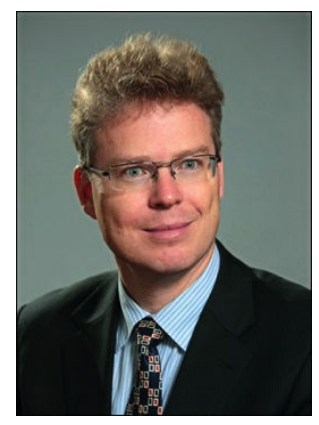

Gatis Bazbauers, Dr.sc.ing., has a diploma of thermal engineering (1990), master of science degree in mechanical engineering (1995), doctor of science degree in engineering (1999) and bachelor's degree in business administration (2002). He works in the Institute of Energy Systems and Environment, Faculty of Energy and Electrical Engineering at Riga Technical University from the year 2000, and currently is a Professor. He worked as a Managing Director in the energy company "Vattenfall Latvia" (1995-2007), as a Project Manager in the energy consulting company "EEE" (1992-1993) and as an Assistant in the Riga Technical University (1990-1993). The main research interests are district heating systems and cogeneration, energy system planning and economics, renewable energy sources, ecodesign, life cycle assessment. Gatis Bazbauers is a member of the council of Latvia's District Heating Association.

Phone: +371 67089911

E-mail: gatis.bazbauers@rtu.lv 